\title{
Increased $5-\mathrm{HT}_{2}$ receptor number in brain as a probable explanation for the enhanced 5-hydroxytryptamine- mediated behaviour following repeated electroconvulsive shock administration to rats
}

\author{
A.Richard Green, Pauline Johnson \& Vishwajit L. Nimgaonkar
}

MRC Clinical Pharmacology Unit, Radcliffe Infirmary, Oxford OX2 6HE

1 Following electroconvulsive shock (ECS) administration daily for 10 days there was an increase $(35 \%)$ in 5-hydroxytryptamine ${ }_{2}\left(5-\mathrm{HT}_{2}\right)$ receptor number in rat frontal cortex $24 \mathrm{~h}$ after the last ECS, compared with handled controls. A similar increase was seen after intermittent ECS administration ( 5 ECS over 10 days) given during halothane anaesthesia, compared with halothane-treated controls. The dissociation constant was also increased at this time. A single ECS had no effect.

2 Treatment of rats with pentylenetetrazol, $p$-chlorophenylalanine or $\alpha$-methyl $p$-tyrosine during the intermittent ECS administration abolished the increase in 5- $\mathrm{HT}_{2}$ receptor binding.

3 Since enhanced 5-HT-mediated behavioural responses are seen after repeated ECS but not when the ECS is given with the drug treatments outlined above, it is suggested that ECS-induced enhancement of 5-HT-mediated behaviour results from an increase in 5- $\mathrm{HT}_{2}$ receptor number.

\section{Introduction}

There is now convincing evidence that repeated administration of electroconvulsive shock (ECS) to rats enhances the response in several 5-hydroxytryptamine- (5-HT)-mediated behavioural models (see, for example, Evans, Grahame-Smith, Green \& Tordoff, 1976; Green Heal \& Grahame-Smith, 1977; Green, Costain \& Deakin, 1980; Lebrecht \& Nowak, 1980).

Recently it has been shown that selective inhibition of 5- $\mathrm{HT}_{2}$ receptors with pirenperone inhibits several of these same behavioural models suggesting that the models are predominantly $5-\mathrm{HT}_{2}$ receptor-mediated (Green, O'Shaughnessy, Hammond, Schăchter \& Grahame-Smith, 1983). The reports, therefore, that cerebral $5-\mathrm{HT}_{2}$ receptor number is increased after repeated ECS (Kellar, Cascio, Butler \& Kurtzke, 1981; Vetulani, Lebrecht \& Pilc, 1981) were of particular interest since they indicated that the enhanced 5-HT-mediated behaviour following repeated ECS might be a direct consequence of an increase in $5-\mathrm{HT}_{2}$ receptor density.

In the binding experiments of Kellar et al. (1981) and Vetulani et al. (1981), only the effect of oncedaily ECS, given for 10 or more days, was examined. However, a course of 5 ECS administered over 10 days to anaesthetized animals, is equally effective in enhancing 5-HT behaviour (Costain, Green \& Grahame-Smith, 1979), a regime which is close to the clinical administration of electroconvulsive therapy (ECT). Administration of $\alpha$-methyl $p$ tyrosine (AMPT), p-chlorophenylalanine (PCPA) or pentylenetetrazol (PTZ) during the period of ECS administration prevents the appearance of enhanced 5-HT-mediated behaviour (Green et al., 1980; Green, Sant, Bowdler \& Cowen, 1982). Administration of intermittent ECS and also the effect of the drug pretreatments have now been examined to determine whether there is a correlation between the appearance of enhanced 5-HT-mediated behaviour and increased $5-\mathrm{HT}_{2}$ receptor number.

\section{Methods}

\section{Animals}

Male Sprague-Dawley derived rats (Charles River, Kent) weighing 100-125 g at the start of treatment were used in all experiments. They were kept housed in groups of 6 in conditions of constant temperature $\left(21^{\circ} \mathrm{C} \pm 1^{\circ} \mathrm{C}\right.$ ) and lighting (light period $07 \mathrm{~h} 00 \mathrm{~min}-19 \mathrm{~h} 00 \mathrm{~min}$ ) and fed an ad libitum diet of modified 41B pellets and tap water. 


\section{ECS and drug administration}

Electroconvulsive shocks were applied through earclip electrodes using a Theratronics (Guernsey) small animal electroplexy unit delivering $125 \mathrm{~V}$ for $1 \mathrm{~s}$ $(50 \mathrm{~Hz})$. In the first experiments either a single ECS $(E C S \times 1)$ or one ECS daily for 10 days $(E C S \times 10)$ was given. This invariably produced a full tonicclonic seizure. Control rats had the electrodes placed but no current was passed.

In all other experiments 5 ECS were given over a period of 10 days (ECS $\times 5$ ) on Mon, Wed, Fri, Mon, Wed, the animals being anaesthetized with halothane. As previously reported (Cowen, Nutt \& Green, 1980), in rats given halothane the seizure is modified, the tonic extension not being seen. Nevertheless, the enhanced behavioural responses are still seen in such animals (Cowen et al., 1980). Control rats received halothane only.

In experiments where drugs were given with the ECS treatment, previously used protocols were adhered to as follows. PTZ (30 $\mathrm{mg} \mathrm{kg}^{-1}$, i.p.) was given $3 \mathrm{~min}$ before each treatment to both ECS and control groups. PCPA (200 $\mathrm{mg} \mathrm{kg}^{-1}$, i.p.) was given to both ECS and control groups $5 \mathrm{~min}$ before the first treatment only. AMPT $\left(200 \mathrm{mg} \mathrm{kg}^{-1}\right.$, i.p.) was given to both ECS and control groups $5 \mathrm{~min}$ before the first treatment and a dose of $50 \mathrm{mg} \mathrm{kg}{ }^{-1}$ before each subsequent treatment. Receptor analysis was always performed $24 \mathrm{~h}$ after the final ECS administration.

\section{Ligand receptor binding}

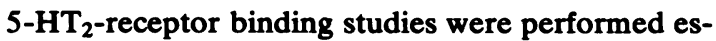
sentially by the method of Rosenfeld a Makman (1981) using $\left[{ }^{3} \mathrm{H}\right]$-spiperone (NEN, specific activity $26.3 \mathrm{Ci} \mathrm{mmol}^{-1}$ ) as the radioligand and lysergic acid diethylamide (LSD) (1 $\mu \mathrm{M}$; Sandoz Pharmaceuticals,
Feltham) as the displacing agent for measurement of specific binding. The frontal cortex, isolated by the method of Bacopoulos (1981) was homogenized in Tris buffer ( $\mathrm{pH}$ 7.2) with a motor driven Teflon homogeniser; both total and non-specific binding was always measured in triplicate. For saturation binding curves three frontal cortices were combined for each plot and the radioligand concentrations used ranged from $0.3 \mathrm{nM}$ to $5.0 \mathrm{nM}$.

Scatchard analysis of the data was performed using linear regression analysis by the method of least squares. Results reported are from at least 3 separate experiments, using different tissue.

Specific binding was determined at a fixed concentration of $\left[{ }^{3} \mathrm{H}\right]$-spiperone in the region of the $K_{d}$ ( $1.3 \mathrm{nM}$; see Table 1$)$, the results being obtained from 6 separate experiments.

\section{Results}

\section{Effect of a single ECS or ECS daily for 10 days on S-HT $\mathrm{T}_{2}$ receptor number}

Twenty-four hours after a single ECS there was no change in either the number of $5-\mathrm{HT}_{2}$ binding sites $\left(B_{\max }\right)$ or the dissociation constant $\left(K_{d}\right)$ compared with a handled control group (Table 1). However, $24 \mathrm{~h}$ after the last of 10 daily ECS there was a marked $(35 \%)$ increase in the number of binding sites (Table 1). The mean dissociation constant value also increased but did not reach statistical significance (Table 1).

\section{Effect of intermittent ECS administration on 5-HT2 receptor number}

Rats were given 5 ECS spread out over 10 days (see

Table 1 Effect of various ECS treatment regimes on 5- $\mathrm{HT}_{2}$ receptor binding characteristics in rat frontal cortex

Treatment
Control (handled)
ECS $\times 1$
ECS $\times 10$
Control (anaesthetized $\times 5$ )
ECS $\times 5$
Control (PTZ)
ECS $\times 5+$ PTZ

\begin{tabular}{|c|c|}
\hline \multicolumn{2}{|c|}{$\begin{array}{l}\text { 5-HT receptor binding characteristics } \\
\mathrm{K}_{d}(\mathrm{nM}) \quad B_{\max }\left(\mathrm{pmol} \mathrm{\textrm {mg } ^ { - 1 }} \text { protein) }\right.\end{array}$} \\
\hline $\begin{array}{l}1.23 \pm 0.09(3) \\
1.32 \pm 0.17(5) \\
1.63 \pm 0.14(6)\end{array}$ & $\begin{array}{l}350 \pm 15(3) \\
379 \pm 38(5) \\
472 \pm 32(6) \dagger\end{array}$ \\
\hline $\begin{array}{l}1.32 \pm 0.01(3) \\
1.65 \pm 0.04(4)\end{array}$ & $\begin{array}{l}356 \pm 7(3) \\
494 \pm 40(4) \dagger\end{array}$ \\
\hline $\begin{array}{l}1.04 \pm 0.07(4) \\
1.02 \pm 0.02(4)\end{array}$ & $\begin{array}{l}275 \pm 24(4) \\
307 \pm 7(4)\end{array}$ \\
\hline
\end{tabular}

5-HT receptor binding characteristics

All measurements were made $24 \mathrm{~h}$ after the last treatment. ECS $\times 1$ is a single ECS, ECS $\times 10$ is ECS once daily for 10 days, ECS $\times 5$ is 5 ECS spread over 10 days. Pentylenetetrazol (PTZ; $30 \mathrm{mg} \mathrm{kg}^{-1}$ ) was given 3 min before the ECS. ECS $\times 5$ treated rats were given halothane anaesthesia. Results are expressed as mean \pm s.e.mean with number of separate experiments given in parentheses. Different from appropriate control: $\uparrow P<0.05 ; * P<0.01$. Correlation coefficient $(r) 0.9$ or better on every analysis. 


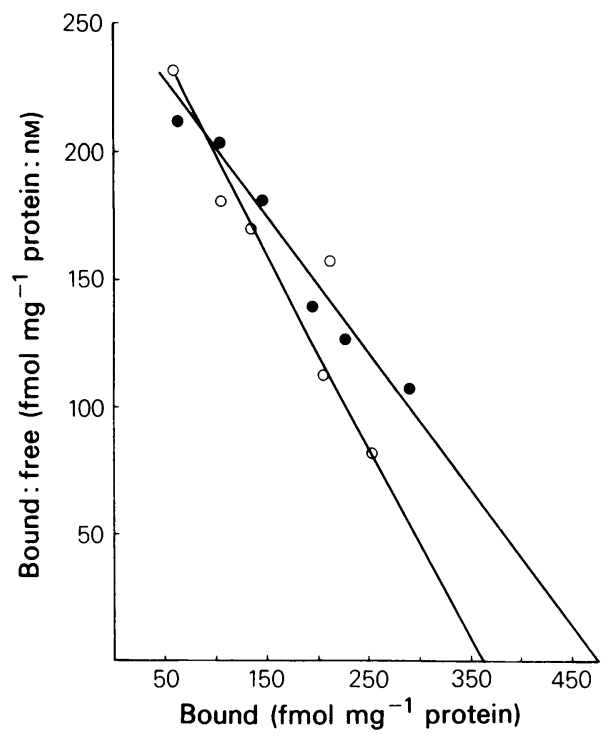

Figure 1 Scatchard analysis of $\left[{ }^{3} \mathrm{H}\right]$-spiperone binding in rats given repeated electroconvulsive shock. Rats were given either 5 exposures to halothane over 10 days (Mon, Wed, Fri, Mon, Wed) (O) or a single ECS during each halothane administration (O) with radioligand binding performed $24 \mathrm{~h}$ after the final treatment. The range of binding concentrations used (see Methods) resulted in the binding curve reaching a plateau. The results above are data from one of the 3 experiments performed and illustrates both the change in $K_{d}$ and $B_{\max }$. Mean values for all the experiments are shown in Table 1.

Methods) whilst anaesthetized with halothane. Control rats received halothane only. Twenty-four hours after the last ECS there was an increase in $5-\mathrm{HT}_{2}$ receptor number (Table 1). The dissociation constant also increased significantly (Table 1 ). This change in the $K_{d}$ is seen in the altered slope of the Scatchard plot (Figure 1).

The increase in receptor number was also reflected in experiments where binding was performed at a fixed concentration of ligand. A large increase in binding was observed after intermittent ECS administration (Table 2).

\section{Effect of injection of pentylenetetrazol before each ECS administration}

Injection of PTZ ( $30 \mathrm{mg} \mathrm{kg}^{-1}$, i.p.) $3 \mathrm{~min}$ before each ECS (5 given over 10 days) prevents the enhancement of 5-HT-mediated behaviour by ECS (Green et al., 1982).

Following an identical treatment pattern no change in $5-\mathrm{HT}_{2}$ binding characteristics were seen in the ECS/PTZ group compared with those in the control group given PTZ alone (Table 1). Whilst mean values for both $K_{d}$ and $B_{\max }$ in the control group were slightly lower than in untreated controls, neither change reached statistical significance.

\section{Effect of inhibiting 5-hydroxytryptamine or catecholamine synthesis on 5-HT2 binding following ECS}

When a fixed ligand concentration was used, a large increase in 5- $\mathrm{HT}_{2}$ receptor binding was observed after intermittent ECS administration (Table 2).

Administration of PCPA $\left(200 \mathrm{mg} \mathrm{kg}^{-1}\right.$, i.p.) $6 \mathrm{~h}$ before the first ECS administration abolished the enhanced binding (results compared with a control group given only PCPA) (Table 2 ).

Similarly, AMPT injection during the course of ECS administration abolished the enhanced binding when compared with the control group given AMPT alone (Table 2).

\section{Discussion}

Kellar et al. (1981) and Vetulani et al. (1981) both reported that daily administration of an ECS for 10 or more days enhanced 5-HT 2 ligand-receptor binding in the rat frontal cortex. Both groups reported that this was due to an increase in the number of receptors $\left(B_{\max }\right)$. However, whilst Kellar et al. (1981) found a single binding site, Vetulani and colleagues

Table 2 Effect of monoamine systhesis inhibition on $\left[{ }^{3} \mathrm{H}\right]$-spiperone binding of rat frontal cortex after repeated ECS

Injected

Saline p-Chlorophenylalanine $\alpha$-Methyl p-tyrosine

\section{Specific bound $\left[{ }^{3} H\right]$-spiperone} Control

$236 \pm 26(6)$

$296 \pm 37(6)$

$315 \pm 12(6)$
$\mathrm{ECS} \times 5$

$$
437 \pm 28(6)
$$$$
283 \pm 58(6)
$$

$272 \pm 25(6)$
Significance

$$
\begin{gathered}
0.001 \\
\text { NS }
\end{gathered}
$$

NS

Results shown as mean \pm s.e.mean of the specifically bound $\left[{ }^{3} \mathrm{H}\right]$-spiperone ( $\mathrm{fmol} \mathrm{mg}^{-1}$ protein) using a concentration of $\left[{ }^{3} \mathrm{H}\right]$-spiperone of $1.66 \mathrm{nM}$ (saline experiment), $1.69 \mathrm{nM}$ (PCPA experiment) and 1.23 nM(AMPT experiment). NS = not significantly different from appropriate control. 
(1981) reported 2 sites, only one of which changed. We also observed only one binding site, but like both groups saw an increase in $B_{\max }$. Furthermore the percentage increase observed was almost identical to that seen previously. However, we also found a change in $K_{\mathrm{d}}$. This failed to reach statistical significance after daily ECS, but was significant after intermittent ECS. The $\boldsymbol{K}_{\mathrm{d}}$ change was similar after both treatments, suggesting that ECS does alter the affinity of the receptor. No change in $5-\mathrm{HT}_{2}$ receptor number or affinity was seen $24 \mathrm{~h}$ after a single ECS, confirming the finding of Kellar et al. (1981).

Kellar et al. (1981) and Vetulani et al. (1981) suggested that the increase in $B_{\max }$ of 5-HT $\mathrm{H}_{2}$ receptors might be the reason that enhanced 5-HTmediated behaviours are seen after ECS. However, this hypothesis remained untested. We have now shown that the increase in $5-\mathrm{HT}_{2}$ receptor number is seen when intermittent ECS is given, and this treatment regime also produces enhanced 5-HTmediated behaviour (Costain et al., 1979). It has also been found that when ECS was given with various drugs known to prevent the enhanced behaviours occurring (see Introduction) there was no increase in

\section{References}

BACOPOULOS, N.G. (1981). Antipsychotic drug effects on dopamine receptors: in vivo binding and in vitro turnover studies. J. Pharmac. exp. Ther., 219, 708-714.

COSTAIN, D.W., GREEN, A.R. \& GRAHAME-SMITH, D.G. (1979). Enhanced 5-hydroxytryptamine-mediated behavioural responses in rats following repeated electroconvulsive shock: relevance to the mechanism of the antidepressive effect of electroconvulsive therapy. Psychopharmacology, 61, 167-170.

COWEN, P.J., NUTT, D.J. \& GREEN, A.R. (1980). Enhanced 5-hydroxytryptamine and dopamine-mediated behavioural responses following convulsions. II. The effects of anaesthesia and current conditions on the appearance of enhanced responses following electroconvulsive shock. Neuropharmacology, 19, 901-906.

DEAKIN, J.F.W. \& GREEN, A.R. (1978). The effects of putative 5-hydroxytryptamine antagonists on the behaviour produced by administration of tranylcypromine and L-DOPA to rats. Br. J. Pharmac., 64, 201-209.

EVANS, J.P.M., GRAHAME-SMITH, D.G., GREEN, A.R. \& TORDOFF, A.F.C. (1976). Electroconvulsive shock increases the behavioural responses of rats to brain 5hydroxytryptamine accumulation and central nervous system stimulant drugs. Br. J. Pharmac., 56, 193-199.

GREEN, A.R., COSTAIN, D.W. \& DEAKIN, J.F.W. (1980). Enhanced 5-hydroxytryptamine and dopaminemediated behavioural responses following convulsions. III. The effects of monoamine antagonists on the ability of electroconvulsive shock to enhance responses. Neuropharmacology, 19, 907-914.

GREEN, A.R., HEAL, D.J. \& GRAHAME-SMITH, D.G.
5- $\mathrm{HT}_{2}$ receptor number. Unfortunately, as the experiments were performed at different times there was some variation in the concentration of ligand used, due to differences in batch and it is therefore not possible to compare the controls following the different drug pretreatments.

The frontal cortex was studied as the $5-\mathrm{HT}_{2}$ receptors in this region have been most clearly characterized. However, 5-HT 2 receptors are widely distributed in the brain including the hind-brain and spinal cord (Peroutka \& Snyder, 1981), areas thought to mediate the 5-HT-induced responses that are enhanced following repeated ECS (Jacobs \& Klemfuss, 1975; Deakin \& Green, 1978).

It seems reasonable to conclude, therefore, that the ECS-induced enhancement of 5-HT-mediated behaviour is the result of an increase in $5-\mathrm{HT}_{2}$ receptor number in the brain, although the mechanisms involved in the production of this increase in receptor number are, at present, unknown.

We thank Sandoz Pharmaceuticals for the generous supply of LSD. V.L.N. is a Rhodes Scholar. Correspondence to A.R.G., please.
(1977). Further observations on the effect of repeated electroconvulsive shock on the behavioural responses of rats produced by increases in the functional activity of brain 5-hydroxytryptamine and dopamine. Psychopharmacology, 52, 195-200.

GREEN, A.R., O'SHAUGHNESSY, K., HAMMOND, M., SCHÄCHTER, M. \& GRAHAME-SMTTH, D.G. (1983). Inhibition of 5-hydroxytryptamine mediated behaviours by the putative $5-\mathrm{HT}_{2}$ antagonist pirenperone. Neuropharmacology, 22, 573-578.

GREEN, A.R., SANT, K., BOWDLER, J.M. \& COWEN, P.J. (1982). Further evidence for a relationship between changes in GABA concentrations in rat brain and enhanced monoamine-mediated behaviours following repeated electroconvulsive shock. Neuropharmacology, 21, 981-984.

JACOBS, B.L. \& KLEMFUSS, H. (1975). Brainstem and spinal cord mediation of serotonergic behavioural syndrome. Brain Res., 100, 450-457.

KELLAR, K.J., CASCIO, C.S., BUTLER, J.A. \& KURTZKE, R.N. (1981). Differential effects of electroconvulsive shock and antidepressant drugs on serotonin-2 receptors in rat brain. Eur. J. Pharmac., 69, 515-518.

LEBRECHT, U. \& NOWAK, J.Z. (1980). Effect of single and repeated electroconvulsive shock on serotonergic system in rat brain. II. Behavioural studies. Neuropharmacology, 19, 1055-1061.

PEROUTKA, S.J. \& SNYDER, S.H. (1981). Two distinct serotonin receptors: Regional variations in receptor binding in mammalian brain. Brain Res., 208, 339-347.

ROSENFELD, M.R. \& MAKMAN, M.H. (1981). The interac- 
tion of lisuride, an ergot derivative, with serotoninergic and dopaminergic receptors in rabbit brain. J. Pharmac. exp. Ther., 216, 526-531.

VETULANI, J., LEBRECHT, U. \& PILC, A. (1981). Enhance- ment of responsiveness of the central serotonergic system and serotonin-2 receptor density in rat frontal cortex by electroconvulsive treatment. Eur. J. Pharmac., 76, 81-85.

(Received March 24, 1983.

Revised May 6, 1983.) 